\title{
Analisis Kebijakan Redaksional Harian Republika pada Pemberitaan Religio-Politik Masa Kampanye Presiden Tahun 2009
}

\author{
Fajriannoor Fanani \\ (carbudit@yahoo.com) \\ Dosen Jurusan Ilmu Komunikas Universitas Semarang
}

\begin{abstract}
Presidential Election in 2009 has gives us some negative phenomenon. The Hijab Campaign, Boediono Wife's Religion, and other religio-politics issues were annoyingly interpolating the better campaigns. In one hand this is a bad phenomenon, but on the other hand this phenomenon also gives us some interesting questions about political tolerance in Indonesia. Mass media as the fourth estate surely can't get away from their responsibility. Uniquely many of big mass media in Indonesia have affiliations with certain religions. The example is Republika with their Muslim affiliations. This phenomenon become interesting to study, moreover Indonesia is one of the biggest democratic countries in the world that surely need political tolerance to strengthen their democratic system. It's become interesting to inquire the editorial policy in Republika in their news on religio-politic in presidential campaign. It's also become interesting to understand the Islamic model that Republika adopted that maybe affected their editorial policy. Last, it's become interesting to find out Republika's political tolerance, especially in the presidential campaign. All of this inquiry could be found using the gatekeeping analysis from Pamela Shoemaker that map out factors that could affect media content from five levels. Those levels are individual, organizational, communication routine, extra-media, and social system.

This research is use post-positivistic paradigm. The theories used here is gatekeeping from Pamela Shoemaker, political tolerance, and moderate Islamic concepts. After analyze using the gatekeeping Analysis, this research found that Republika's policy for the religio-politics issues have vision of moderat Islamic model that generally careful but will be serious and sensasional if when dealing with syariah policy issues. Last, Republika have a limited political tolerance policy that have tendency to be exclusive and difficult to accommodate the aspiration of non-Muslim peoples.

The final conclusion for this research is that Republika have an editorial policy that creates public space for Indonesian Muslim that has vision of Islamic moderate and limited political tolerance.
\end{abstract}

Key Words: Gatekeeping, Islam Moderat, Toleransi Politik

\section{PENDAHULUAN}

"Politik primordial telah mati", itulah kesimpulan Lembaga Survei Indonesia (LSI) pada 9 Juli 2009. Survei mereka kala itu menunjukkan bahwa tokoh-tokoh ormas Islam tidak lagi memiliki pengaruh yang berarti pada masyarakat yang lebih memilih berdasarkan pertimbangan rasional.
Kesimpulan ini kemudian juga di dukung oleh hasil pemilu legislatif 2009 yang menunjukkan tidak populernya partai-partai berbasis agama seperti PKS dan PAN. PKS misalnya hanya mampu meraih suara $7,88 \%$ dengan perolehan kursi DPR 10,18 \% (Mega Prabowo Sepakat. (15 Mei 2009). Suara Merdeka: 1). Hal ini tentu jauh dari 
target mereka untuk memperoleh suara hingga 20\% (Semangat Populis Partai Dakwah. (30 Maret - 5 April). Tempo: 51). Bahkan PAN sebagai partai Islam yang berimage paling moderat pun hanya dapat memperoleh suara $6,01 \%$ dan 43 kursi DPR (Mega Prabowo Sepakat. (15 Mei 2009). Suara Merdeka: 1). Jauh dari target mereka untuk memperoleh 100 kursi (Satu Mentari Dua Warna. (30 Maret - 5 April). Tempo: 69).

Fenomena ini, walaupun berakibat negatif pada partai-partai Islam, menunjukkan gambaran yang positif bagi tumbuhnya demokrasi di Indonesia. Berdasarkan survey tersebut dapat di ambil kesimpulan bahwa masyarakat tidak lagi terpengaruh oleh berbagai isu agama dalam memilih calon yang dikehendaki baik eksekutif maupun legislatif. Masyarakat beragama di Indonesia telah dapat berperilaku toleran secara politik dengan menghindari kedekatan agama tertentu untuk memutuskan pilihannya. Toleransi politik ini menjadi penting karena menurut Bernard Lewis ujian untuk melihat apakah civil society ada atau tidak di negara-negara Muslim adalah toleransi. Sementara itu, Schmitter menegaskan bahwa civil society memberi kontribusi pada konsolidasi demokrasi, karena ia membantu menciptakan toleransi di antara warga negara (Mujani, 2007: 153). Toleransi politik dengan demikian dibutuhkan oleh semua negara demokratis, terutama Indonesia yang tidak hanya berupaya untuk menjadi demokratis, namun juga memiliki masyarakat yang majemuk dan pluralistik.

Sayangnya berbagai fenomena "miring" pada masa kampanye presiden 2009 tampaknya menunjukkan bahwa fenomena toleransi ini masih masih terlalu dini untuk diamini. Pada saat itu mulai berkembang isu-isu politisasi agama yang seringkali menyerang pasangan-pasangan calon tertentu. Isu yang paling gencar saat itu adalah isu yang mengabarkan bahwa Herawati, istri dari Boediono, adalah seorang penganut agama Katolik. Isu miring tersebut segera saja di tampik oleh tim kampanye SBY-Boediono (Raden Trimutia Hatta. (2009). Tuduhan Istri Boediono Katolik tak Bermoral. Dalam http://www.inilah.com/ berita/ politik/ 2009/06/02/112012/ tuduhan-istri-boedkatolik-tak-bermoral/. Diunduh pada tanggal 21 Juni 2009 pukul 20:55 WIB). Isu keagamaan dari Boediono dan Herawati tersebut kemudian menjadi memanas di masa kampanye karena dikomunikasikan dalam selebaran yang disebarkan pada saat kampanye pasangan JK-Win.

Fenomena negatif di masa kampanye ini menunjukkan bahwa toleransi politik di Indonesia tampaknya belum merasuk pada elit politik di Indonesia, lalu bagaimana dalam media massa? Media massa sebagai alat dari komunikasi massa tidak hanya memiliki kemampuan untuk menyebarkan informasi kepada masyarakat, mereka juga mampu menjadi agen transmisi budaya yang memelihara konsensus budaya dan selalu hadir dalam berbagai bentuk komunikasi yang mempunyai dampak pada penerimaan individu (Nurudin, 2004: 71). Pandangan ini menganalogikan bahwa media massa Indonesia seharusnya lepas dari berbagai afiliasi keyakinan dan bersikap sebagai mediator serta ruang publik bagi seluruh rakyat Indonesia. Sayangnya realitanya tidaklah demikian karena banyak media massa di Indonesia yang memiliki latar belakang afiliasi dengan agama tertentu dan secara praktik masih terjebak dalam favoritisme agama afiliasi mereka. Praktik tersebut bahkan juga terjadi pada media-media besar umum seperti 
Kompas yang memiliki afiliasi kuat dengan kelompok Katolik, Suara Pembaruan yang berafiliasi dengan umat Kristen Protestan, dan terutama Republika yang memiliki afiliasi kuat dengan kelompok Muslim.

Terkait dengan Republika ini mereka lebih berani dan eksplisit dalam memberitakan berbagai isu agama dalam kampanye politik. Pada Edisi 1 Juni 2009 misalnya, Republika mengeluarkan tulisan berjudul $J K$ : Jangan Suruh Istri Saya Lepas Jilbab (Republika, 1 Juni 2009: Hal 8, kolom 6). Pemberitaan itu terkait dengan tudingan bahwa pasangan $J K$-Win menggunakan kedua istri mereka yang berjilbab untuk kampanye. Republika juga mengeluarkan pemberitaan pada edisi 9 Juni 2009 yang berjudul, “'Ekonomi Syariah Opsi Serius" (Republika, 9 Juni 2009, hal: 1, kolom 2). Pemberitaan tersebut berisi mengenai pernyataan Boediono yang bernada positif terhadap ekonomi syariah dan menyatakannya sebagai prosektor riil. Kemudian terkait dengan isu mengenai istri Boediono Republika tampaknya memberitakan dengan hatihati. Berita tersebut mulai di muat dalam koran edisi 25 Juni 2009 dengan judul berita, "Istri Boediono Diserang" (Republika, 25 Juni 2009, hal: 5, kolom 2). Isi pemberitannya sendiri cukup singkat karena hanya di beri ruang satu kolom serta sama sekali tidak menyebutkan agama yang diisukan pada istri Boediono, yaitu Katolik. Republika kemudian mengikuti isu tersebut dengan memberikan pemberitaan berjudul, "Kasus Herawati Boediono di-Bawaslu-kan" (Republika, 26 Juni 2009, hal: 4, kolom 1), yang diterbitkan pada edisi 26 Juni 2009. Pemberitaan itu berisi keinginan pihak partai Demokrat untuk melaporkan isu selebaran gelap tersebut pada Badan Pengawas Pemilu (Bawaslu). Berita tersebut juga telah secara eksplisit menunjukkan agama yang di"gosipkan" pada ibu Herawati, yaitu Katolik, akan tetapi secara keseluruhan pemberitaannya juga tidaklah terlalu mencolok.

Fenomena tersebut menimbulkan beberapa pertanyaan yang menarik untuk diteliti. Bagaimanakah kebijakan Republika saat memberitakan isu religio-politik dalam masa kampanye presiden dan wakil presiden tahun 2009 lalu? Apa kebijakan model ke-Islaman Republika itu sendiri? Dan bagaimanakah toleransi politik Republika dalam pemberitaan tersebut? Tujuan dari penelitian ini dengan demikian adalah untuk memahami kebijakan redaksional Republika dalam pemberitaan religio-politik, pada masa kampanye presiden tahun 2009.

\section{TINJAUAN PUSTAKA}

Republika sendiri selama ini telah banyak dijadikan subyek penelitian oleh para akademisi. Penelitian Agus Sudibyo misalnya mencoba untuk memahami prasangka antar umat beragama dalam pemberitaan Republika melalui analisis bahasa ${ }^{1}$. Dalam penelitian tersebut Agus Sudibyo menyimpulkan media Islam seperti Republika lebih berani dalam memberikan evaluasi-evaluasi yang mensiratkan prasangka negatif tentang kelompok-kelompok Kristen (Sudibyo dkk, 2001:173). Lalu ada juga penelitian Mansyur Semma (1998) yang melakukan studi gatekeeping dan analisis isi terhadap pemberitaan Republika terkait isu peristiwa Timor Timur dan Situbundo. Dalam penelitian tersebut ditemukan bahwa Republika,

\footnotetext{
Dalam penelitiannya Agus Sudibyo mengambil sampel dari empat isu pemberitaan, yaitu kasus Kerusuhan di Kupang, Ketapang, dan Maluku serta Kasus Pengeboman Masjid Istiqlal di Jakarta.
} 
terutama terkait peristiwa Timor Timur, cenderung meneguhkan sikap gatekeeper Republika yang lebih memihak pada kepentingan umat Islam (Semma, 1998: 233 dan 244). Konsep Toleransi Politik sementara itu telah banyak di teliti oleh para ilmuwan. Penelitian ini sendiri banyak merujuk pada penelitian kuantitatif Saiful Mujani mengenai hubungan antara Islam dan Demokrasi di Indonesia Pada penelitian itu sendiri Mujani menemukan bahwa toleransi politik Muslim Indonesia tergolong cukup walaupun tidak dapat dikatakan tinggi (Mujani, Saiful, 2007: 316-317).

Penelitian ini menggunakan paradigma post-positivistik yang bergerak dari paradigma positivistik namun tidak sama sekali menolak asumsi-asumsi paradigma tersebut seperti halnya paradigma interpretive dan critical. Secara ontologis paradigma post-positivistik menerima pandangan realis bahwa fenomena berlangsung secara independen dari persepsi dan teori mengenai fenomena tersebut. Postpositivistik juga menerima pandangan social constructionist melalui dua cara. Pertama, mereka meyakini bahwa proses konstruksi sosial berlangsung dalam pola yang tetap dan dapat diamati melalui cara-cara investigasi social scientific. Individu memiliki free will dan kreativitas, namun mereka umumnya sering berperilaku dengan cara yang telah terpola dan mudah diduga. Kedua, mereka berpandangan bahwa konstruksi sosial dibentuk secara regular dan dijadikan sebagai tujuan bagi para aktor dalam dunia sosial, sehingga sangat dimungkinkan untuk mempelajari hasil dari pembentukan konstruksi tersebut (Miller, 2005: 39).

Indonesia yang menjadi melting pot dari berbagai kultur dan agama dunia memiliki potensi laten bagi konflik bernuansa SARA. Hal ini tentu bertentangan dengan konsep demokrasi itu sendiri karena demokrasi dapat berjalan dengan baik apabila terdapat "penerimaan warga Negara dan para elite politik atas prinsip-prinsip yang mendasari kebebasan berbicara, berserikat, beragama, dll" (Lipset dalam Mujani 2007: 153). Kebebasan tersebut dapat berjalan apabila terdapat suatu toleransi politik yang signifikan pada civil society. Toleransi politik mengindikasikan adanya penerimaan suatu kelompok masyarakat terhadap kelompok lain untuk berpolitik dan bernegara yang pada akhirnya melestarikan sistem demokrasi karena toleransi memberikan kemampuan untuk bersikap dan berperilaku adil serta obyektif terhadap berbagai opini, tradisi, agama, nasionalisme, dll yang berbeda dari kita. Civil society sendiri sangat terkait dengan toleransi politik karena civil society mencerminkan adanya keadilan, persamaan di depan hukum, transparasi, akuntabilitas, dan kejujuran sebagai landasan bermasyarakat. Konsep ini menjadi kontekstual bagi Indonesia karena kompleksitas bangsa ini yang tersusun dari berbagai kelompok dan agama di mana perbedaan tersebut lebih sering di politisir ketimbang dijadikan sebagai berkah.

Penelitian ini akan menggunakan analisis gatekeeping untuk menemukan jawaban tujuan penelitian, akan tetapi sebelumnya penelitian juga akan melakukan analisis tekstual untuk mendapatkan data tambahan yang mungkin berguna sebagai pembanding. Analisis tekstual yang digunakan sendiri di ambil menurut analisis semiotika Saussure. Saussure meletakkan tanda dalam konteks komunikasi manusia dengan melakukan pemilahan antara apa yang disebut signifier (penanda) dan signified (petanda). Signifier adalah bunyi yang bermakna atau coretan yang bermakna (aspek ma- 
terial), yakni apa yang dikatakan dan apa yang di tulis atau di baca. Signified adalah gambaran mental, yakni pikiran atau konsep aspek mental dari bahasa. (Sobur, 2004: 125). Saussure juga berpendapat bahwa makna dihasilkan melalui proses seleksi dan kombinasi tanda di sepanjang proses sintagmatis dan paradigmatik. Poros sintagmatis di bangun oleh kombinasi linear antar tanda yang membentuk kalimat. Poros paradigmatik mengacu kepada arena tanda (misalnya sinonim) yang darinya segala tanda yang ada di seleksi. Makna diakumulasikan di sepanjang poros sintagmatik, sementara seleksi dari arena paradigmatik mengubah makna pada poin tertentu dalam kalimat (Barker, 2005: 70).

Secara kasar gatekeeping dapat dianalogikan sebagai proses dimana jutaan pesan yang tersedia di dunia ini diseleksi dan diubah menjadi ratusan pesan yang diterima oleh individu tertentu dalam waktu tertentu (Shoemaker, 1991: 1). Ada banyak model gatekeeper yang bermunculan, seperti model Bass. Bass membagi dua tipe gatekeeper berdasarkan fungsinya. Tipe pertama adalah news gatherer yang mencari dan memperoleh berita mentah dari berbagai channel dan mengubahnya menjadi copy berita. Tipe kedua adalah news processor yang memodifikasi dan menyatukan copy berita kedalam produk jadi yang dapat ditransmisikan ke audiens (Shoemaker, 1991: 14, 15). Model Bass ini telah memadukan unsur reporter dan editor yang umum hadir dalam ruang media massa, sehingga modelnya sangat aplikatif untuk digunakan. Sementara itu Pamela Shoemaker sendiri telah merumuskan suatu analisis gatekeeping yang kompleks dan memperhatikan berbagai aspek. Analisis gatekeeping ini sendiri di ambil berdasarkan teori
Shoemaker dan Reese mengenai faktorfaktor yang mempengaruhi isi media.

Faktor-faktor ini antara lain:

1. Faktor individual, yang sangat dipengaruhi oleh faktor pendidikan, pengalaman, kesukuan, agama, jender, dan sikap individu terhadap peristiwa yang dilaporkannya

2. Faktor rutinitas media, yang terkait dengan rutinitas yang biasa dilakukan media untuk mengolah berita yang masuk dari berbagai pintu berita, termasuk salah satunya dari reporter

3. Faktor organisasi, yang ditentukan oleh struktur yang ditetapkan oleh poal-pola reguler perilaku yang saling bertautan

4. Faktor ekstra media yang datang dari luar media, dan

5. Faktor ideologi yang ditentukan dari kerangka berfikir atau referensi tertentu yang di pakai oleh individu untuk melihat realitas dan bagaimana mereka menghadapinya (Shoemaker and Reese, 1996: 183 dan Syahputra, 2006: 54-60)

\section{METODOLOGI PENELITIAN}

Tipe penelitian yang akan dilakukan adalah penelitian kualitatif dekstriptif dengan pendekatan analisis gatekeeping menurut Pamela Shoemaker. Subyek dalam penelitian ini adalah surat kabar Republika. Harian ini dipilih karena dikenal luas telah menjadi representasi umat Islam terutama di daerah Jakarta. Data primer dari penelitian ini adalah hasil wawancara dari pihak-pihak yang memahami kebijakan pemberitaan dari Harian Republika. Pihak-pihak ini dapat meliputi wartawan, editor, litbang, dan pihak lainnya yang dapat menjawab pertanyaan mengenai kebijakan pemberitaan dalam kedua harian tersebut. Redaktur senior atau pimpinan redaksi bagaimanapun juga lebih 
diutamakan karena sangat terkait dengan level kebijakan dari harian itu sendiri. Sementara itu data sekunder penelitian ini adalah data teks pemberitaan yang terkait dengan kampanye pemilihan presiden yang bermuatan agama. Oleh karena itu surat kabar yang di pilih adalah yang terbit selama masa kampanye, yaitu mulai tanggal 2 Juni hingga 4 Juli 2009. Akan tetapi penyempitan ini tidak menutup kemungkinan untuk mengambil contoh berita lain di luar masa kampanye asalkan memiliki wacana serupa. Selain itu data sekunder juga diperoleh dari berbagai bacaan dan digunakan untuk melengkapi data yang dibutuhkan penelitian ini.

Teknik pengumpulan data yang digunakan dalam penelitian ini adalah wawanvara dan Studi Kepustakaan. Teknik wawancara ditujukan untuk memperoleh data langsung dari redaksional pemberitaan surat kabar Republika. Studi kepustakaan sementara itu digunakan untuk memperoleh teks pemberitaan koran Republika serta memperoleh bahan-bahan analisis di luar media. Sementara itu langkahlangkah penelitian akan di ambil sesuai dengan tahapan analisis gatekeeping Shoemaker yang akan menganalisis secara bertahap seluruh unsur gatekeeping tersebut, yang meliputi analisis individual, organisasi, rutinitas komunikasi, ekstramedia, dan sistem sosial.

Sesuai dengan paradigma postpositivistik penelitian ini berpegang pada objektivitas perolehan data dan otentisitas serta kredibilitas data yang didapat. Objektivitas adalah kualitas pikiran dimana peneliti dapat memisahkan properti nyata dari fenomena yang diteliti dari bias dan prasangka atau prejudice (Bloor and Wood dalam Turner, 2006: 420). Sementara itu validitas data secara sederhana dapat dikatakan sebagai kebenaran data. Kita bisa mendeskripsikan sesuatu sebagai valid sejauh kita bisa menjelaskan bahwa ia benar-benar merepresentasikan apa yang diklaim untuk direpresentasikan (Bruce and Yearley, 2006: 313). Kriteria terakhir yang ingin dipenuhi dalam penelitian ini adalah kriteria ketepatan data. Kriteria ketepatan data ini lebih mengacu pada narasumber yang diwawancarai dimana mereka adalah orang-orang yang tepat bagi penelitian ini, yaitu wartawan yang menjalankan kebijakan redaksional di lapangan dan wakil pimpinan redaksi yang turut menentukan kebijakan redaksional harian Republika.

Terakhir penelitian ini memiliki beberapa keterbatasan. Pertama, penelitian ini diharapkan memperoleh banyak data dari Republika, terutama data wawancara, akan tetapi ternyata selama penelitian sulit sekali mendapatkan akses pada pihak-pihak yang berkepentingan, sehingga penelitian ini harus melengkapinya dengan data-data wawancara lain yang mungkin dapat ditemukan melalui sumber-sumber lain seperti internet. Berikutnya penelitian ini juga hanya melakukan pengkajian teks dan produksi berita harian Republika dalam isu politisasi agama (religio-politik). Artinya hasil dari penelitian ini tidak dapat disamakan begitu saja terhadap isu-isu lain yang mungkin sering dikaitkan juga dengan Harian Republika, seperti isu konflik agama.

\section{PEMBAHASAN}

Sebelum analisis gatekeeping
dilakukan, penelitian ini
mengemukakan terlebih dahulu hasil
analisis semiotika yang telah dilakukan
pada teks pemberitaan religio-politik
harian Republika. Ada beberapa isu
religio-politik yang muncul dalam


pemberitaan Republika semasa musim kampanye 2009 lalu. Secara garis besar isu-isu tersebut meliputi:

a. Isu Kampanye Jilbab. Isu tersebut diberitakan oleh Republika pada tanggal 1 Juni 2009 dengan judul "JK: Jangan Suruh Istri Saya Lepas Jilbab".

b. Isu Istri Boediono Nasrani. Isu tersebut mulai diberitakan oleh Republika pada tanggal 25 Juni 2009 dengan judul "Istri Boediono Diserang". Kemudian di susul dengan pemberitaan pada tanggal
26 Juni 2009 dengan judul "Kasus Herawati Boediono di-Bawaslukan."

c. Isu Kebijakan Syariah. Isu tersebut paling terlihat pada pemberitaan Republika tanggal 9 Juni 2009 dengan judul "Ekonomi Syariah Opsi Serius". Isu ini juga terlihat pada pemberitaan tanggal 27 Juni 2009 dengan judul "SBY: Peran Islam Penting" dan tanggal 28 Juni dengan judul "Muhammadiyah Memberi Panduan Memilih Presiden".

Hasil analisis semiotika dari seluruh pemberitaan ini sendiri dapat dilihat dalam tabel-tabel berikut yang meringkas seluruh analisis semiotikan tersebut.

\section{Tabel 1}

Tabel Analisis Teks Berita "JK: Jangan Suruh Istri Saya Lepas Jilbab"

\begin{tabular}{|l|l|}
\hline \multicolumn{2}{|c|}{ Sintagmatik } \\
\hline Rangkaian Tanda & Arti Rangkaian \\
\hline Pernyataan Jusuf Kalla & $\begin{array}{l}\text { Sikap tegas Jusuf Kalla yang menolak isu kampanye jilbab } \\
\text { seraya membela penggunaan jilbab istrinya karena perintah } \\
\text { agama }\end{array}$ \\
\hline \hline \multicolumn{1}{|c|}{ Paradigmatik } \\
\hline Pilihan Tanda & Konsekuensi Pilihan \\
\hline Kutipan Kalla & $\begin{array}{l}\text { Merepresentasikan Jusuf Kalla sebagai pembela agama di } \\
\text { mana dia dengan tegas menentang ide yang bersinggungan } \\
\text { dengan keyakinannya sebagai umat Islam }\end{array}$ \\
\hline Kutipan Yuddy & $\begin{array}{l}\text { Menunjukkan kesalehan Mufida Kalla dan Uga Wiranto } \\
\text { karena telah mengenakan jilbab }\end{array}$ \\
\hline
\end{tabular}

\section{Tabel 2}

\section{Tabel Analisis Teks Berita "Istri Boediono Diserang"}

\begin{tabular}{|l|l|}
\hline \multicolumn{3}{|c|}{ Sintagmatik } \\
\hline Rangkaian Tanda & Arti Rangkaian \\
\hline Keseluruhan Berita & $\begin{array}{l}\text { Adanya selebaran negatif yang beredar selama Jusuf Kalla } \\
\text { melakukan kampanye di berbagai daerah. Selebaran ini menyerang } \\
\text { pribadi istri Boediono yang di isukan sebagai non Muslim }\end{array}$ \\
\hline \hline \multicolumn{2}{|c|}{ Paradigmatik } \\
\hline Pilihan Tanda & Konsekuensi Pilihan \\
\hline Frasa diserang & $\begin{array}{l}\text { Memberikan kesan stereotipis bahwa menjadi non- } \\
\text { Muslim dalam dunia politik di Indonesia sangatlah tidak } \\
\text { menguntungkan }\end{array}$ \\
\hline Frasa bukan beragama Islam & Memberikan kesan netral yang berhati-hati \\
\hline
\end{tabular}




\section{Tabel 3}

Tabel Analisis Teks Berita "Kasus Herawati Boediono di-Bawaslu-kan"

\begin{tabular}{|c|c|}
\hline \multicolumn{2}{|r|}{ Sintagmatik } \\
\hline Rangkaian Tanda & Arti Rangkaian \\
\hline Berita utama & $\begin{array}{l}\text { Mengikuti perkembangan dari tim kampanye SBY-Boediono } \\
\text { yang berniat melaporkan isu kampanye negatif istri Boediono } \\
\text { non-Muslim pada Bawaslu }\end{array}$ \\
\hline Sub berita al-fatihah & $\begin{array}{l}\text { Kasus istri Boediono tersebut dapat diselesaikan dengan mudah } \\
\text { dengan cara menyuruh Herawati Boediono untuk membaca surat } \\
\text { al-Fatihah }\end{array}$ \\
\hline \multicolumn{2}{|r|}{ Paradigmatik } \\
\hline Pilihan Tanda & Konsekuensi Pilihan \\
\hline Frasa Katolik & $\begin{array}{l}\text { Pemilihan frasa ini dengan segera membuat keseluruhan isu } \\
\text { menjadi lebih kultural dengan mempertemukan pertentangan } \\
\text { klasik Islam-Nasrani }\end{array}$ \\
\hline Kutipan Al-Fatihah & $\begin{array}{l}\text { Pemilihan kutipan tersebut membuat isu politik yang ada lebih } \\
\text { bergeser menjadi isu agama dimana solusi yang paling mudah } \\
\text { untuk menyelesaikan permasalahan ini adalah dengan solusi } \\
\text { agama }\end{array}$ \\
\hline Kutipan Pancasila & $\begin{array}{l}\text { Pemilihan kutipan ini sedikit meredakan situasi panas karena } \\
\text { kutipan al-Fatihah dengan mengembalikan permasalahan ke spirit } \\
\text { nasional kebangsaan yang multikultural }\end{array}$ \\
\hline
\end{tabular}

\section{Tabel 4}

Tabel Analisis Teks Berita "Ekonomi Syariah Opsi Serius"

\begin{tabular}{|c|c|}
\hline \multicolumn{2}{|c|}{ Sintagmatik } \\
\hline Rangkaian Tanda & Arti Rangkaian \\
\hline Berita secara umum & $\begin{array}{l}\text { Isu yang sangat penting bagi audiens bankan cenderung } \\
\text { sensasional sehingga layak ditempatkan sebagai berita utama }\end{array}$ \\
\hline $\begin{array}{l}\text { Tidak terla } \\
\text { berkampany } \\
\text { tengah berd }\end{array}$ & $\begin{array}{l}\text { Tidak terlalu digambarkan sebagai cawapres yang tengah } \\
\text { berkampanye, namun lebih seperti pengamat ekonomi yang } \\
\text { tengah berdiskusi }\end{array}$ \\
\hline $\begin{array}{l}\text { Sangat posi } \\
\text { unggul dari } \\
\text { penyelamat }\end{array}$ & $\begin{array}{l}\text { Sangat posistif, system yang sangat membela sektor riil, lebih } \\
\text { unggul dari system ekonomi konvensional, dan dapat menjadi } \\
\text { penyelamat untuk keluar dari krisis ekonomi dunia }\end{array}$ \\
\hline \multicolumn{2}{|c|}{ Paradigmatik } \\
\hline Pilihan Tanda & Konsekuensi Pilihan \\
\hline Frasa Sektor Riil dan Derivatif & $\begin{array}{l}\text { Memberikan argumen yang rasionil dan intelek } \\
\text { untuk mendukung sistem ekonomi syariah } \\
\text { sebagai sistem yang paling baik }\end{array}$ \\
\hline $\begin{array}{l}\text { Frasa mantan Gubernur Bank Indonesia, } \\
\text { Menteri Keuangan, dan Menteri } \\
\text { Koordinator Prerekonomian }\end{array}$ & $\begin{array}{l}\text { Membawa Boediono lebih sebagai pengamat } \\
\text { ekonomi dengan pengalaman yang mumpuni di } \\
\text { bidang perekonomian dan keuangan daripada } \\
\text { sebagai calon wakil presiden }\end{array}$ \\
\hline Kutipan dua pengamat ekonomi lain & $\begin{array}{l}\text { Mempertegas keunggulan sistem ekonomi syariah } \\
\text { dan membawa berita lebih kepada berita ekonomi } \\
\text { daripada berita mengenai calon wakil presiden } \\
\text { yang sedang berkampanye }\end{array}$ \\
\hline 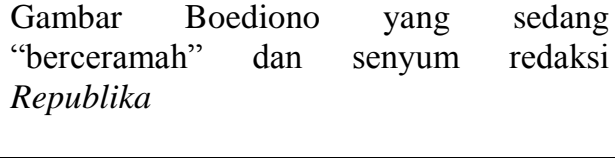 & $\begin{array}{l}\text { Dengan jelas menunjukkan dukungan Republika } \\
\text { terhadap segala yang diutarakan oleh Boediono, } \\
\text { yaitu pernyataannya mengenai kebaikan sistem } \\
\text { ekonomi syariah }\end{array}$ \\
\hline
\end{tabular}


Tabel 5

Tabel Analisis Teks Berita "SBY: Peran Islam Penting"

\begin{tabular}{|c|c|c|}
\hline \multicolumn{3}{|r|}{ Sintagmatik } \\
\hline Rangkaian Tanda & \multicolumn{2}{|c|}{ Arti Rangkaian } \\
\hline Berita secara umum & \multicolumn{2}{|c|}{$\begin{array}{l}\text { memandang serius isu tersebut dan ingin } \\
\text { merepresentasikan wacana berita ini sebagai sesuatu hal } \\
\text { yang juga penting bagi masyarakat }\end{array}$} \\
\hline Islam & \multicolumn{2}{|c|}{$\begin{array}{l}\text { Islam memang memiliki stigma yang negatif dan buruk } \\
\text { akan tetapi Islam adalah agama yang toleran dan dapat } \\
\text { beradaptasi dengan demokrasi, terutama di Indonesia }\end{array}$} \\
\hline$\overline{\text { SBY }}$ & \multicolumn{2}{|c|}{$\begin{array}{l}\text { Digambarkan secara positif sebagai muslim yang santun } \\
\text { dan perduli terhadap kondisi dunia Islam saat ini }\end{array}$} \\
\hline \multicolumn{3}{|r|}{ Paradigmatik } \\
\hline \multicolumn{2}{|l|}{ Pilihan Tanda } & Konsekuensi Pilihan \\
\hline \multicolumn{2}{|c|}{ Judul SBY: Peran Islam Penting } & $\begin{array}{l}\text { Dengan tegas menunjukkan keinginan } \\
\text { Republika untuk menonjokan peran penting Is- } \\
\text { lam dalam dunia politik }\end{array}$ \\
\hline \multicolumn{2}{|c|}{$\begin{array}{l}\text { Kutipan kalimat Islam, demokrasi, } \\
\text { dan modernitas bisa berdampingan }\end{array}$} & $\begin{array}{l}\text { Berusaha menginformasikan bahwa Islam } \\
\text { tidaklah kuno, kolot, atau tertinggal, melainkan } \\
\text { selaras dengan nilai-nilai modern }\end{array}$ \\
\hline \multicolumn{2}{|l|}{ Frasa Harian Umum } & $\begin{array}{l}\text { Seolah-olah menyingkir dari peran Republika } \\
\text { selama ini sebagai harian Islam, sehingga } \\
\text { dengan demikian penilaian positif Islam dalam } \\
\text { berita tersebut dapat di promosikan sebagai } \\
\text { penilaian dari media yang umum, bukan parti- } \\
\text { san }\end{array}$ \\
\hline
\end{tabular}

Tabel 6

Tabel Analisis Teks Berita "Muhammadiyah Beri Panduan Memilih Presiden"

\begin{tabular}{|l|l|}
\hline \hline \multicolumn{2}{|l|}{ Sintagmatik } \\
\hline Rangkaian Tanda & Arti Rangkaian \\
\hline Umat Islam dan Muhammadiyah & $\begin{array}{l}\text { Kaum yang terabaikan karena aspirasi syar'i } \\
\text { mereka telah lama diabaikan oleh pemerintah }\end{array}$ \\
\hline \hline \multicolumn{1}{|c|}{ Paradigmatik } \\
\hline Pilihan Tanda & Konsekuensi Pilihan \\
\hline Kutipan terakhir Din Syamsudin & $\begin{array}{l}\text { Seolah-olah menunjukkan bahwa umat } \\
\text { Muhammadiyah khususnya dan Islam umumnya } \\
\text { selama ini tidak di dengar aspirasinya. Apabila } \\
\text { dicermati maka aspirasi tersebut terkait dengan } \\
\text { berbagai kebijakan syariah yang selama ini di } \\
\text { dorong oleh Republika, seperti ekonomi syariah, } \\
\text { RUU Makanan Halal, dll. Padahal telah banyak } \\
\text { kebijakan pemerintah yang mengakomodasi } \\
\text { syariah seperti UU APP, Sisdiknas, dll. }\end{array}$ \\
\hline
\end{tabular}


Setelah itu, sebelum melakukan analisis gatekeeping menurut Pamela Shoemaker, penelitian ini akan menunjukkan terlebih dahulu proses dan alur produksi berita dari harian Republika. Alur produksi ini sendiri dapat dilihat dalam gambar berikut"

\section{Gambar 1}

\section{Diagram Alur Produksi Berita Harian Republika}

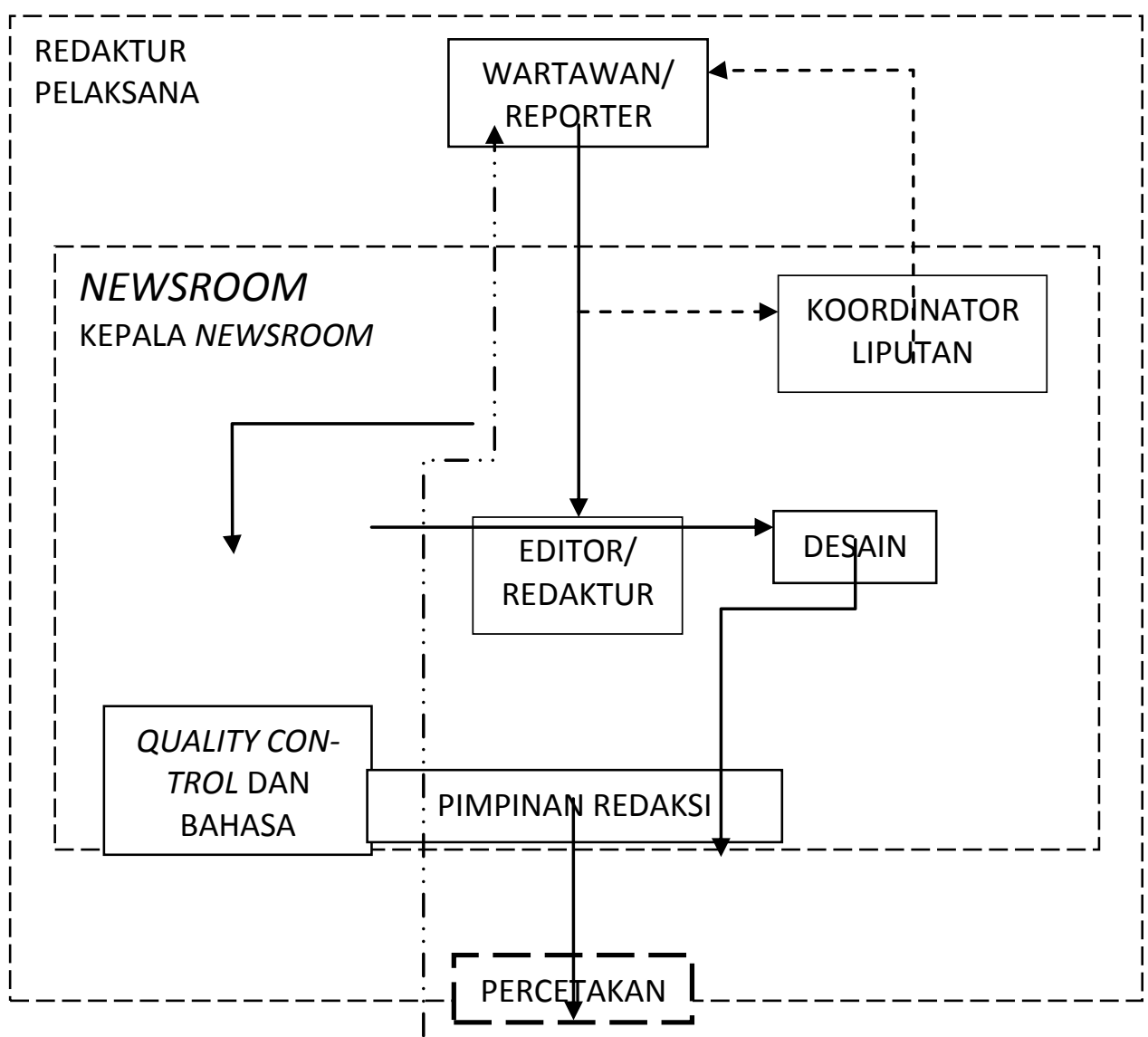

Keterangan:

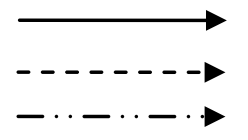

Alur Berita

Alur Koordinasi Berita

Feedback dari Pimpinan Redaksi

Wartawan Republika berpegang pada kaidah-kaidah jurnalistik yang normatif. Tidak ada arahan khusus mengenai bagaimana cara meliput isuisu yang menyerempet ke arah SARA. Kaidah jurnalisme umum nampaknya dianggap telah cukup untuk memandu wartawan dalam menulis pemberitaan yang bijak, terutama saat menyerempet pada isu-isu SARA. Wartawan Republika dituntut untuk tetap meletakkan peristiwa itu secara proporsional dan menulisnya sebagai produk berita. Mereka menyerahkan kepada masyarakat mengenai penilaian atau akibat yang mungkin muncul dari pemberitaan tersebut. Sementara itu terkait isu-isu yang dinilai sensitif untuk umat Islam, Republika tetap mewajibkan wartawannya untuk meliput pemberitaan tersebut selama berita itu memang layak diketahui oleh khalayak. Akan tetapi mereka juga memiliki arahan yang menarik dimana 
mereka diminta untuk tidak memperkeruh suasana dan mengadu domba antar umat Islam. Hal inilah yang mungkin membuat Republika banyak dinilai lembut dan berhati-hati dalam memberitakan isu-isu terorisme dan kerusuhan. Hal ini jugalah yang membuat Republika terkesan sangat berhati-hati dalam memberitakan isu Istri Boediono, karena isu tersebut memiliki kecenderungan yang membenturkan umat Islam. Di lain pihak Republika terkesan sangat bombastis saat memberitakan isu Ekonomi Syariah, karena isu ini tidak membenturkan umat dan malah cenderung menyatukannya.

Sementara itu editor atau redaktur Republika memang dituntut untuk menyeleksi berita sesuai dengan identitas Republika sebagai Koran umat Islam. Ini bukan berarti bahwa mereka sama sekali tidak memberitakan isu-isu yang tidak menyinggung umat Islam, mereka hanya memberikan porsi dan highlite yang lebih besar pada peristiwa atau isu yang bersentuhan dengan umat Islam. Ini menjawab pertanyaan mengapa berita-berita kebijakan syariah dan Islam seperti berita ekonomi syariah pada masa kampanye menjadi penting untuk dimuat. Mereka juga tegas mengatakan telah menerapkan prinsip-prinsip keberimbangan dengan baik dengan selalu adanya cover both side, cek dan ricek, berhati-hati dalam menggunakan sumber yang anonym, dll. Ketika disinggung bagaimana redaksional mereka menyikapi pemberitaan yang memiliki potensi memecah umat, mereka menjawab dengan jawaban yang hampir serupa diberikan oleh wartawan mereka. Umumnya mereka mengatakan bahwa Republika adalah harian umat Islam Indonesia sehingga mereka selalu berusaha untuk berdiri ditengah-tengah umat Islam. Akan tetapi mereka juga mengasosiasikan diri mereka sebagai Islam mainstream yang sepaham dengan demokrasi dan menolak model Islam yang terlalu radikal dan terlalu liberal.

Pimpinan Redaksi dalam struktur Republika memiliki kuasa untuk menentukan apakah seluruh susunan koran telah layak untuk dicetak setelah seluruh layout Koran selesai disusun. Ia dapat menolak beberapa berita untuk diterbitkan atau meminta koreksi dan penambahan terhadap berita tersebut. Kebanyakan isu-isu yang dipilih sebagai berita utama pada masa itu memang isu-isu seputar kampanye presiden, menariknya peristiwa yang dipilih untuk di follow-up biasanya berhubungan dengan umat Islam. isuisu ini dipilih karena proximity atau kedekatan peristiwa tersebut dengan umat Islam Indonesia sebagai pasar dari Republika. Alasan kedekatan ini jugalah yang membuat wacana ekonomi syariah yang dibawakan Boediono saat berkunjung ke Republika dipilih sebagai berita utama. Fenomena yang berbeda ditemui saat mereka menghadapi isu istri Boediono non-Muslim yang berkaitan dengan umat Islam juga. Mereka memang melakukan follow-up terhadap isu tersebut akan tetapi memilih untuk agak menjaga jarak denga berhati-hati saat memberitakannya. Kemudian saat ditanya mengenai isu jilbabisasi politik mereka juga menganggapnya seirama dengan isu sebelumnya yang tidak tulus, sarat kepentingan, dan sebenarnya tidak pantas untuk dijadikan berita. Terhadap kedua isu ini mereka memilih untuk memberitakannya secara sepintas tanpa ada highlight tertentu didalamnya.

Setelah menelusuri alur produksi berita harian Republika penelitian ini melakukan analisis gatekeeping menurut Pamela Shoemaker pada redaksional Republika. Level yang 
pertama kali diteliti disini adalah level individu yang dapat dilihat dari value, karakteristik, dan role conception dari pekerja media Republika. Berdasarkan value-nya, mayoritas pekerja media dalam tubuh Republika adalah umat Islam, dan apabila ada umat non-Muslim yang bekerja di sana maka mereka tidak ditempatkan dalam posisi-posisi redaksional yang dapat menentukan kebijakan isi media. Umat Islam yang bekerja di sana rata-rata juga merupakan simpatisan ormas terbesar di Indoenesia, yaitu NU, walaupun simpatisan ormas-ormas lain pun ada, seperti Muhammadiyah, Persis, dan Jama'ah Tabligh. Akan tetapi hal ini pun tidak menciptakan sebuah perbedaan pandangan dalam tubuh Republika karena secara umum sikap para individu pekerja media tersebut juga sama dengan sikap resmi Republika yang juga sama dengan sikap mainstream umat Islam di Indonesia, yaitu Islam Moderat.

Kemudian berdasarkan karakteristiknya, secara motivasional mereka dipengaruhi oleh nilai-nilai yang mendorong mereka untuk mendakwahkan khasanah ke-Islaman dalam setiap pemberitaan mereka. Akan tetapi mereka juga mengkompromikannya dengan kebutuhan dan kepentingan yang berkembang, dalam kasus istri Boediono misalnya awak Republika menghindar dari isu sensitif tersebut karena semata-mata isu tersebut di pandang tidak tulus, politis, dan hanya ditujukan untuk menyerang pasangan capres-cawapres lainnya. Republika sebaliknya akan dengan antusias dan serius membahas permasalahan itu apabila tidak ada niatan jelek dibelakangnya, artinya isu mengenai "ketidak-Islaman" istri calon wakil presiden, wakil presiden, atau bahkan presiden bagi Republika merupakan isu yang penting dan dapat di bahas secara mendalam. Republika dengan demikian tidaklah berniat untuk menghindar dari isu SARA, akan tetapi hanya melihatnya sebagai maneuver politik praktis yang kotor.

Terakhir, berdasarkan role conception-nya, Republika tidak hanya memandang dirinya sekedar sebagai penyalur informasi pada khalayak Muslim. Sebaliknya mereka juga berusaha menjadi agen perubahan bagi khalayak Muslim dengan pemberitaanpemberitaan yang terpilih. Mereka menjadi disseminator yang tidak hanya melakukan seleksi berita namun juga "pembungkusan" berita di mana ada unsur-unsur tertentu yang ditonjolkan (highlight) ataupun dipendam demi kepentingan agenda mereka. Pada isu kebijakan syariah misalnya, mereka terlihat melakukan penonjolan pada berbagai keunggulan sistem syariah dan Islam itu sendiri hal ini menunjukkan bahwa mereka memiliki agenda untuk mendorong masyarakat Islam untuk lebih memahami khasanah dunia Islam, dan juga mendorong pemerintah untuk lebih memperhatikan syariah Islam. Sementara itu dalam isu Istri Boediono dan kampanye jilbab mereka terlihat lebih berhati-hati dan menuliskan pemberitaan secara lebih pasif.

Pada level yang berikutnya, organisasi, penelitian ini mencoba melihat perubahan visi perusahaan mereka dari koran politik menjadi koran bisnis. Mereka mengaku sebagai koran non-partisan, akan tetapi dalam sejarahnya, sebelum di akuisisi oleh Mahaka Media, mereka selalu memiliki sikap membela pemerintahan atau partai tertentu. Pada saat pemerintahan Soeharto mereka dengan jelas menjadi oposisi, setelah itu pada masa pemerintahan B.J. Habibie mereka menjadi pendukung utama, pada saat Gus Dur memimpin mereka awalnya 
mendukung namun akhirnya ikut menjadi oposisi. Di sini jelas terlihat bahwa pada masa lalu Republika tidaklah terlalu netral dan selalu mendukung pihak-pihak yang memberikan efek positif bagi umat Islam Indonesia. Sikap Republika sebagai harian politik Islam ini ternyata membawa beberapa konsekuensi penting di akhir tahun 2000. Paska krisis moneter daya beli masyarakat menurun dan pendapatan dari iklan juga turut menurun. Sikap sebagai Harian Politik juga di nilai menjadi sebab penurun jumlah pengiklan, karena sebagian besar pemasang iklan juga memiliki kepentingan politik yang berbeda (Anif Punto Utomo, 2010: 53).

Pada saat Republika nyaris bankrut itulah Mahaka Media masuk dan menggantikan PT. Abdi Bangsa sebagai pemilik. Bersamanya juga ikut di bawa beberapa perubahan. Status Republika sebagai koran politik di hapus dan digantikan dengan idiom-idiom organisasi bisnis profesional. Isi harian pun banyak yang diubah dengan mengurangi porsi politik dan menambah feature-feature Islami yang digemari oleh pembaca. Bergesernya paradigma Republika dari harian politik menjadi harian bisnis juga tentunya turut membawa falsafah baru dalam "kehidupan" mereka. Falsafah ini adalah hukum klasik kapitalisme yang wajib dimiliki oleh setiap organisasi bisinis, yaitu hukum permintaan dan penawaran. Akan tetapi mesti dilihat juga bahwa walau telah menjadi lembaga bisnis Republika tetap tidak mau meninggalkan misi atau agenda "dakwah"nya. Agenda inilah yang tetap memberikan warna Islam yang berwawasan pada isi harian tersebut. Mereka berusaha mensinergikan antara kepentingan bisnis dan agenda dakwah mereka. Mereka mengakui bahwa mereka tidak bisa memaksakan agenda mereka kepada masyarakat dan memilih untuk memasukinya melewati agenda masyarakat yang sepaham dengan mereka. Republika dengan demikian tidaklah menghamba $100 \%$ pada permintaan audiens Muslim mereka, malahan mereka seperti melakukan seleksi untuk menentukan agenda audiens mana yang sesuai dengan visi mereka dan bisa "garap".

Pada level yang berikutnya, ekstra media, penelitian berusaha menyoroti faktor-faktor pengaruh yang datang dari luar ruang redaksi, dalam hal ini audiens, media lain, dan pemilik. Bagi Republika audiens dan pasar menjadi faktor yang sangat penting untuk di kelola dengan baik. Hal ini dikarenakan mereka memiliki pangsa pasar yang sangat ter-segmented, yaitu umat Islam Indonesia dari kelas profesional menengah ke atas. Republika bukanlah semata-mata media yang berupaya untuk memakasakan agenda ke-Islaman tertentu terhadap masyarakatnya. Harian ini, sama seperti media bisnis lain, juga masih memiliki concern terhadap masalah ekonomi mereka yang ditandai dengan upaya untuk memenuhi keinginan pembaca mereka. Kemudian apabila ada pengaruh dari media besar lain pengaruh tersebut mungkin lebih bersifat antagonis dalam artian pemberitaan Republika lebih bersifat mengimbangi dan memberikan alternatif pandangan lain terhadap suatu isu yang diberitakan oleh harian lain. Hal ini lebih jelas terlihat saat isu konflik agama merebak di mana Republika cenderung berupaya memberikan pandangan yang lebih membela kelompok Islam ketimbang media lain. Pada isu RUU APP dan RUU Sisdiknas Republika juga terlihat memberikan pandangan alternatif yang mendukung kedua RUU tersebut dibandingkan dengan media lain, 
terutama Kompas, yang cenderung menolak kedua RUU tersebut.

Sementara itu terkait dengan kepemilikan Republika ada fakta menarik bahwa Republika dalam sejarahnya telah memiliki dua pemilik. Pemiliki pertama adalah ICMI melalui PT Abdi Bangsa yang sangat kental dengan aroma Muhammadiyah. Republika pada masa itu dibangun untuk menjadi Koran politik yang mencerdaskan kehidupan politik umat Islam yang selama ini dinilai tertekan. Setelah itu pada tahun 2000 mereka berganti pemilik ke Mahaka Media yang hampir tidak memiliki afiliasi keagamaan sama sekali. Sebagai pemilik mereka tidak pernah mengintervensi kebijakan redaksional Republika karena bagi mereka Republika semata-mata hanyalah bisnis. Visi, misi, dan kultur ke Islaman suara merdeka lebih banyak di peroleh dari pemilik lama mereka, yaitu ICMI yang notabene memiliki afiliasi ke Islaman yang kuat dan merupakan bagian dari revivalisme Islam di Indonesia pada tahun 1990an.

Pada level yang terakhir penelitian berusaha melihat pengaruh yang datang dari situasi sosio kultural atau ideologi yang berkembang dimana media tersebut berdiri. Sejak dari awal pendiriannya Republika memang telah ditujukan bagi umat Islam, menurut Anif Punto Utomo dalam buku Republika 17 Tahun Melintas Zaman disebutkan bahwa Republika didirikan karena adanya kegelisahan umat Islam karena merindukan hadirnya koran bernafaskan Islam. Mereka merasakan adanya ketidakseimbangan arus informasi karena media-media besar di Indonesia adalah justru media nonIslam. Hal ini tentunya tentunya memperjelas positioning, visi, dan ideologi umum Republika, yaitu sebagai harian komunitas umat Islam, apalagi hal ini dipertegas juga dengan pernyataan Habibie di masa lalu bahwa penjualan saham Republika hanya ditujukan untuk umat Islam (Republika edisi 19 Januari 1993 dalam Anif Punto Utomo, 2010: 38, 39). Ideologi dasar dari Republika dengan demikian telah jelas, yaitu Islam, kemudian pertanyaan selanjutnya yang belum terjawab adalah ideologi umat Islam yang bagaimana? Dan bagaimana hal tersebut mempengaruhi proses produksi teks secara sosial?

Apabila melihat sejarah dari Republika yang didirikan oleh ICMI dengan tokoh-tokohnya seperti Syafi'i Anwar, Dawam Rahardjo, dan Imaduddin Abdurrohim yang adalah tokoh Muhammadiyah maka wajar apabila kemudian pengaruh Muhammadiyah terasa lebih kuat dalam harian tersebut akan tetapi mereka mengaku berusaha untuk lepas dari kesan tersebut dan menampung seluruh umat Islam Indonesia. Arys Hilman selaku Wakil Pimpinan Redaksi Republika juga mengatakan bahwa mereka tidak memiliki afiliasi dengan ormas manapun, akan tetapi pemikiran dan sikap mereka sama seperti ormasormas mainstream di Indonesia, secara spesifik ia menyebut Muhammadiyah dan NU yang moderat. Apabila Republika mengaku bahwa sikap mereka sama seperti sikap kedua ormas besar tersebut maka dapat disimpulkan bahwa sikap resmi mereka adalah Islam yang moderat dimana model Islam ini tidaklah anti demokrasi, radikal, dan skriptualistik. Sebaliknya mereka mendukung dan berperan aktif dalam kegiatan demokratis di Indonesia, seperti pemilu. Lingkungan Islam yang moderat dan toleran semacam inilah yang mungkin membuat Republika tak segan mengaku bahwa visi Islam mereka adalah Islam yang moderat, 
sesuai dengan mainstream Muslim di Indonesia.

Setelah melakukan analisis mendalam menggunakan Analisis Semiotika Saussure dan Gatekeeping dari Pamela Shoemaker, dapat diketahui visi Islam model apa yang di adopsi oleh Republika sebagai kebijakan redaksional mereka. Mengacu pada analisis terhadap tiga isu tersebut, yaitu Isu Kampanye Jilbab, Isu Istri Boediono Katolik, dan Isu Kebijakan Syariah, dapat diketahui bahwa secara umum kebijakan Republika terhadap isu-isu religio politik adalah bahwa apabila isu tersebut sensitif, tidak tulus, dan penuh kepentingan maka isu tersebut tidak perlu dipermasalahkan, di blow up atau di-cover secara serius dan mendalam untuk pemberitaan. Sementara itu jika isu tersebut menonjolkan aspek-aspek khasanah Islam, terutama dalam tata negara, maka isu tersebut perlu di cover secara mendalam, intens, dan bahkan di ulas secara bombastis.

Kemudian melalui serangkaian wawancara yang telah dilakukan terhadap wartawan dan redaktur senior Republika, penelitian ini memperoleh pengakuan resmi bahwa visi dan afiliasi keagamaan mereka adalah Islam moderat. Dalam hal ini mereka mengambil contoh bahwa sikap mereka memiliki banyak kesesuaian dengan pandangan dua ormas besar Islam di Indonesia yang memiliki garis pemahaman Islam moderat, yaitu Muhammadiyah dan Nahdlatul Ulama (NU). Kemoderatan Republika ini juga dapat dilihat dalam dua hal, yaitu:

1. Republika memberikan highlite yang besar pada isu-isu kebijakan syariah, seperti isu ekonomi syariah dan isu peranan Islam. Sekilas sensasionalitas semacam ini nampak juga hadir dalam bahasa kaum fundamentalis, di mana segala hal yang berbau Islam murni akan dibesar-besarkan, akan tetapi Republika selalu membungkus isu tersebut dalam kerangka kampanye pilpres yang notabene demokratis. Republika sementara itu juga masih protektif membungkus isu-isu yang beraroma SARA, hal yang tidak ditemukan pada kelompok radikal.

2. Secara tekstual juga tidak ditemukan kata atau frasa yang sering digunakan oleh kelompok radikal/fundamentalis. Menurut $\mathrm{M}$. Yudhie Haryono pada diri fundamentalis terkandung bahasa perlawanan, jihad (holy war). Kelompok fundamentalis juga gemar memunculkan isu-isu Muslim versus Yahudi dan Nasrani, WTC, Osama bin Ladin, kristenisasi, zionisme dan lampiran ayat-ayat Al Qur'an yang menjustifikasi kewajiban melawan musuh. Yudhie Haryono juga mengatakan bahwa perlu ada dekonstruksi teks terhadap frasafrasa Kafir, Musyrik, Munafiq, dan Murtad yang sering digunakan oleh kelompok fundamentalis (Yudhie Haryono, 2005: 89, 95, dan 107). Berdasarkan konsepsi ini maka memang tidak ditemukan model frasa atau kata dalam teks Republika, dan bahkan dalam wawancara, yang sama digunakan dengan kelompok fundamentalis.

Berdasarkan kedua hal ini menjadi jelas bahwa Republika memiliki pemahaman yang sama sekali berbeda dengan kelompok Islam fundamental atau radikal. Premisnya benarbenar tidak sesuai dari awal, yaitu sikap terhadap demokrasi dan negara bangsa di mana kelompok fundamentalis sangat menentang demokrasi dan nasionalisme, sementara Republika mendukungnya. Kemudian Republika juga tidak memiliki kesesuaian dengan 
model Islam liberal. Mereka mengatakan dengan tegas bahwa Republika tidaklah memiliki sikap yang sesuai dengan Ulil Abshar Abdallah, Gus Dur, dan pemikir liberal lain yang sejenis $^{2}$. Sikap ini juga dipertegas dengan hasil-hasil analisis tekstual terutama pada pemberitaan kebijakan syariah. Pada isu ini Republika terlihat sekali sangat getol memberitakan berbagai kebijakan syariah terutama ekonomi syariah. Sikap ini jelas sangat berseberangan dengan sikap kelompok liberal yang menolak segala produk agama dalam ruang publik. Bagi kelompok ini agama adalah spirit yang akan mendorong, memupuk, dan mengiringi kehidupan seseorang secara positif, tetapi produk agama itu sendiri tidak boleh dipaksakan pada kehidupan publik yang cosmopolitan dan melibatkan banyak umat. Sikap Republika dengan demikian juga jauh dari sikap model Islam yang liberal atau sekuler.

Republika dengan demikian tidaklah menganut Civil society secara penuh dan lebih mirip dikatakan mengaplikasikan apa yang di sebut sebagai Civil Islam. Aspek dukungan terhadap syariat Islam melalui sistem yang demokratis dan Civil Islam ini dengan jelas menunjukkan bahwa Republika berada ditengah-tengah spectrum model ke-Islaman, yaitu moderat. Visi moderat yang mengedepankan civil Islam inilah yang merupakan kebijakan dasar bagi Republika. Seluruh proses produksi berita yang mereka lakukan haruslah disesuaikan dengan visi moderat yang mendukung demokrasi, nasionalisme, profesionalisme dan

\footnotetext{
2 Dalam wawancara penulis bertanya bagaimana pandangan Republika terhadap tokoh-tokoh ini dan Arys Hilman menjawab bahwa mereka bukan mainstream, oleh karena itu Republika tidak memiliki sikap yang sama dengan mereka.
}

peningkatan kualitas hidup umat Islam Indonesia.

Telah jelas bahwa Republika menjalankan sebuah model Islam yang sering di sebut sebagai Islam Moderat. Apakah model ke-Islaman semacam ini tergolong toleran secara politik? Apakah Republika juga telah memperlihatkan toleransi tersebut? Mengingat Toleransi Politik merupakan prasayarat yang dibutuhkan untuk menciptakan sebuah Civil society. Untuk memahami hal tersebut penelitian ini akan menelusuri sikap Republika terhadap negara, umat beragama lain, dan umat Islam lain.

Terkait dengan hubungan Republika dengan negara perlu dipahami bahwa kelompok moderat tidaklah memandang pemerintah sebagai institusi yang tidak Islami atau haram untuk diikuti, akan tetapi mereka juga tidak mau mengakui bahwa negara ini menganut sistem sekuler yang memisahkan agama dan negara. Dalam politik mereka sangat berbaur dengan sistem demokratis yang ada. Mereka mengikuti pemilu melalui parpol-parpol Islam, mereka ikut menyusun semua perundangan pemerintah, mereka bahkan berkoalisi dengan parpol lain yang berhalauan nasionalis. Sikap Republika terhadap pemerintah juga menunjukkan hal yang sama. Walaupun bernafaskan Islam Republika tidak menganggap negara dan sistem demokrasi sebagai "barang" yang haram. Arys Hilman sendiri selaku Wakil Pimpinan Redaksi mengatakan dengan tegas bahwa mereka tidaklah anti terhadap demokrasi dan sepaham dengan sistem tersebut. Tanda lain dari toleransi tersebut adalah gencarnya pemberitaan Republika semasa kampanye pemilihan presiden dengan ikut menyajikan berita-berita terkait kampanye tersebut, seperti profil calon dan kegiatan kampanye. Republika 
bahkan menerima beberapa calon presiden dan wakil presiden kedalam redaksi mereka sebagai bagian dari kampanye kepresidenan, Hal ini menunjukkan bahwa Republika memiliki kebijakan yang sangat toleran terhadap pemerintah dan bahkan ikut berpartisipasi dalam sistem tata pemerintahan dan demokrasi, hal mana sikap tersebut sangat sesuai dengan sikap kelompok Islam moderat Indonesia.

Terkait dengan sikap Republika terhadap umat Islam lain perlu dipahami bahwa kelompok Islam moderat memiliki visi yang tidak sama dengan kelompok Islam radikal dan liberal, akan tetapi mereka juga memiliki sikap yang tergolong ambigu terhadap kedua kelompok tersebut. Mereka tidak tegas mengutuk atau mendukung aksi dan pandangan dari kelompok Islam radikal. Pada satu sisi mereka menolak aksi terorisme dari kelompok tersebut, namun pada sisi yang lain mereka juga menyetujui pandangan kelompok ini mengenai ketidakadilan yang di terima oleh umat Islam di dunia. Selain terhadap kelompok fundamental mereka juga memiliki sikap yang cenderung bimbang terhadap kelompok liberal yang sebagian besar berasal dari kelompok mereka sendiri ${ }^{3}$. Mereka contohnya mendukung konsep-konsep dialog antar pemeluk agama dan pluralitas yang sering disuarakan oleh kelompok Islam Liberal, akan tetapi mereka juga menghindari isu-isu sensitif seperti reinterpretasi Al Qur'an dan hadits. Kesimpulan yang dapat di ambil adalah bahwa kelompok moderat memiliki toleransi politik yang baik dalam mengakomodir kelompok Islam

Tokoh-tokoh Islam Liberal seperti Gus Dur dan Ulil Abshar Abdallah sebagian besar berasal dari ormas-ormas Islam besar yang moderat, dalam hal ini Nahdlatul Ulama (NU) lainnya yang tidak sepaham dengan mereka.

Republika sendiri, sebagai harian dengan visi Islam moderat, mengemukakan bahwa mereka tetap mengakomodir kelompok-kelompok Islam lainnya dalam harian mereka, contohnya meliput kegiatan HTI yang dikenal anti terhadap demokrasi. Akan tetapi, selama masa kampanye, hal ini ternyata kurang dapat ditemukan di lapangan. Republika tidak pernah memuat tulisan-tulisan dari kelompok fundamentalis yang terkenal anti terhadap demokrasi. Republika tidak pernah memuat tulisan $A b u$ Bakar Ba'asyir yang pernah mengharamkan pemilihan umum, atau tulisan HTI yang mengajak untuk tidak memilih. Mungkin saja Republika memiliki kebijakan toleransi sosial dengan menampung kegiatan demonstrasi mereka, akan tetapi tampaknya dalam level politik hal ini tidak terjadi. Yang menarik saat ini Republika juga tengah gencar didemonstrasi oleh FPI karena di anggap mendukung pemutaran film "?" (baca: "Tanda Tanya") yang dinilai oleh banyak kalangan mempromosikan sekularisme, pluralism, dan liberalism. Hal ini kurang lebih menunjukkan bahwa Republika, dalam menghadapi isu-isu non-konflik (contohnya konflik Poso, Ambon, dll), tampaknya memiliki kebijakan moderat yang lebih toleran pada kelompok liberal ketimbang fundamental.

Terkait sikap Republika terhadap umat beragama lain perlu dipahami bahwa toleransi politik dalam artian seluruh umat beragama memberikan kesempatan yang $100 \%$ sama bagi umat beragama lain untuk berpartisipasi dalam politik mungkin belum dapat ditemukan pada umat Islam Indonesia. Akan tetapi dalam level tertentu toleransi semacam ini telah biasa ditemukan. Artinya hubungan umat Is- 
lam dan non-Muslim dalam politik sama sekali tidak berada dalam titik yang mengkhawatirkan. Lalu bagaimana dengan Republika? Sebagai harian untuk komunitas Muslim tampak jelas bahwa Republika kesulitan memberikan ruang yang sama bagi kelompok non-Muslim. Hal ini terlihat dari sedikitnya pemberitaan mengenai partisipasi umat non-Muslim dalam kampanye kepresidenan. Tercatat selama masa kampanye tersebut hanya ada dua pemberitaan politik dari umat non-Muslim. Terkait dengan isu "Istri Boediono Katolik" Republika juga tampak melakukan eksklusi terhadap umat Katolik, karena secara tersirat dikatakan bahwa menjadi umat Katolik sangatlah tidak menguntungkan dalam dunia perpolitikan Indonesia. Terakhir dan yang paling terlihat adalah minimnya kesempatan bagi umat nonMuslim untuk bergabung dan menjadi seorang jurnalis di Republika. Situasi ini tentu menyebabkan produksi berita yang kurang berimbang bagi umat nonMuslim karena hampir seluruh proses gatekeeping dikuasai oleh umat Islam.

Kesimpulannya, dalam level politik Republika belum dapat memberikan kebijakan toleransi yang sama bagi umat non-Muslim. Kebijakan toleransi politik yang ditawarkan oleh mereka adalah toleransi yang terbatas ala Islam moderat yang hanya "mampu" memberikan keadilan politik dalam level politik yang rendah namun "lumpuh" dalam memberikan keadilan dalam level yang lebih tinngi. Akan tetapi dalam level sosial ada gejala yang lebih positif, ditandai dengan kesediaan mereka membuat kampanye anti korupsi yang menghadirkan banyak tokoh agama.
Republika secara tegas mengatakan bahwa mereka adalah harian umat Islam dan diperuntukkan bagi umat Islam. Lebih lanjut mereka juga mengatakan memiliki visi yang serupa dengan visi kelompok moderat yang modern dan profesional. Artinya mereka memiliki kerangka kebijakan yang mendukung demokrasi, modernitas, nasionalisme, antikekerasan dan atribut moderat lainnya. Sebaliknya mereka tidak medukung atribut fundamentalis yang menolak demokrasi dan atribut liberalis yang menolak kebijakan syariah. Atribut moderat ini juga muncul dalam banyak teks Republika yang mendukung demokrasi melalui peliputan-peliputan kampanye kepresidenan yang intens.

Republika sebagai bagian dari kelompok Islam moderat Indonesia memiliki toleransi sosial yang baik terhadap umat non-Muslim. Pada isu anti korupsi, kerukunan umat beragama, dll Republika mau menggandeng tangan umat Katolik. Akan tetapi pada level toleransi politik Republika masih kesulitan memberikan kesempatan yang lebih luas bagi umat non-Muslim untuk menyampaikan pendapatnya. Hal ini terlihat dari minimnya pemberitaan kampanye dari kelompok non-Muslim, bahasa yang mengekslusi kelompok Katolik dalam pemberitaan isu Istri Boediono Katolik, dan minimnya (apabila tidak bisa dikatakan tidak ada) jurnalis Republika yang beragama nonMuslim. Kondisi ini menyebabkan munculnya atmosfir eksklusivitas agama dalam Republika yang memisahkan antara kelompok Islam dan non-Muslim bagi Republika. Seolah-olah Republika berkata bahwa urusan politik di Indonesia seharusnya dikendalikan oleh umat Islam, karena umat inilah yang mayoritas di negara ini.

Kesimpulan umum dari kebijakan PENUTUP redaksional Republika adalah 
menciptakan wadah bagi umat Islam Indonesia dengan visi Islam moderat dan toleransi politik yang terbatas. Hal ini dapat di lihat dari bagaimana Republika mendorong komunitas umat Islam untuk aktif dalam berpolitik, bernegara, dan berdemokrasi. Dukungan Republika tersebut tertuang dalam setiap pemberitaannya yang mengulas berbagai partisipasi umat Islam dalam kegiatan politik dan demokrasi seperti kegiatan partai-partai Islam, kampanye calon presiden untuk mendukung massa Islam, dll. Republika dengan demikian berperan dalam menghapuskan depolitisasi era orde baru terhadap umat Islam di Indonesia dan memberi kontribusi bagi peningkatan kecerdasan serta kesadaran terhadap politik bagi umat Islam di Indonesia.

Secara akademis penelitian ini dapat memperkaya kajian ilmu komunikasi dalam media massa, terutama agama dalam media massa yang dikaitkan dengan konsep toleransi politik. Dengan menggunakan metode analisis gatekeeping penelitian ini berhasil menemukan faktor-faktor yang mempengaruhi redaksional Republika dan mempengaruhi toleransi politik mereka. Penelitian ini dengan demikian telah berhasil mengkaji toleransi politik dalam media massa menggunakan analisis dalam dunia ilmu komunikasi. Lebih lanjut penelitian ini diharapakan dapat membuka pintu peneliti-peneliti lain untuk melakukan penelitian disekitar tema toleransi politik dalam media massa dalam perspektif yang berbeda-beda. Penelitian ini secara khusus merekomendasikan untuk melakukan penelitian dalam perspektif kritis dan melihat bagaimana Republika, atau media-media berafiliasi agama lain, mungkin berusaha untuk melakukan eksklusi sebagai bagian dari kontestifikasi umat beragama di Indo- nesia dalam mempengaruhi agenda kebijakan pemerintah.

Secara praktis penelitian ini diharapkan dapat memberikan kontribusi bagi pelaku industri media dalam menjalankan kerja jurnalistik mereka, terutama dalam memberitakan isu-isu religio-politik dalam kampanye politik. Penelitian ini secara khusus telah menunjukkan bahwa nilai-nilai, ideologi, dan pandangan keagamaan aktor media massa dapat mempengaruhi kebijakan redaksional media mereka. Sebenarnya apa yang dilakukan Republika dengan menjadi media Islam tidaklah menjadi permasalahan. Peneliti sendiri berkeyakinan bahwa untuk kondisi masyarakat Indonesia saat ini yang sangat mulitkultural maka dibutuhkan penyaluran aspirasi yang tepat bagi masing-masing kelompok tersebut. Republika adalah salah satu saluran aspirasi ini yang diperuntukkan bagi kelompok Islam moderat dan modern Indonesia. Akan tetapi penelitian ini juga merekomendasikan pemangku kebijakan Republika untuk lebih terbuka dengan umat diluar kelompok dan bahkan agama mereka, sehingga diharapkan akan terjadi diskusi yang konstruktif sekaligus menghindarkan Republika untuk menjadi suatu Groupthink ${ }^{4}$.

Penelitian ini juga diharapkan mampu memberikan kontribusi pada

\footnotetext{
Groupthink adalah teori komunikasi kelompok yang dikembangkan oleh Irving Janis. Teori tersebut mengasumsikan bahwa sebuah kelompok yang terlalu kohesif dapat berubah menjadi Groupthink yang eksklusif, protektif, dan anti kritik. Setiap kelompok masyarakat dapat menjadi Groupthink yang merasa paling tahu sendiri (Illusion of invulnerability), selalu membenarkan diri excuse (rationalize), merasa yang paling benar dan bermoral (inherent morality), selalu memberikan stereorype negatif bagi kelompok lain (stereotyped), anti kritik, dan self censorship (Janis dalam Littlejohn, 1999: 287-289).
} 
kehidupan bermasyarakat, terutama terkait dengan kehidupan masyarakat Indonesia yang multikultural dan multi keyakinan sehingga demokrasi, pluralisme, civil society, dan toleransi politik menjadi isu yang krusial. Penelitian ini dengan jelas menunjukkan bahwa Republika sebagai media Islam tidak musti menghantam segala isu beraroma agama. Mereka juga kerap berhati-hati dalam memberitakan suatu isu, terutama yang memiliki kecenderungan membenturkan antar umat Islam. Artinya bagi masyarakat sebenarnya tidak ada masalah untuk menjadi pelanggan dari sebuah media komunitas agama, akan tetapi diharapkan mereka lebih memahami posisi media tersebut dan tidak menganggapnya sebagai penyedia informasi tunggal dan pasti benar bagi mereka. Masyarakat diharapkan tidak hanya mengikuti satu media komunitas agama mereka saja. Masyarakat juga diharapkan untuk juga mengikuti media-media lain yang berbeda dengan media komunitas mereka sehingga sirkulasi informasi tidak hanya berasal dari media komunitas tersebut. Hal ini diharapkan dapat menghindari masyarakat menjadi apa yang telah disebutkan sebelumnya, Groupthink.

\section{REFERENSI}

\section{Referensi Buku}

Barker, Chris. (2005). Cultural Studies: Teori dan Praktik. Kreasi Wacana: Yogyakarta

Bruce, Steve and Steven Yearley. (2006). The Sage Dictionary of Sociology. London: Sage Publications

Littlejohn, Stephen W. (1999). Theories of Human Communication $6^{\text {th }}$ ed. London: Wadsworth

Miller, Katherine. (2005). Communication Theories:
Perspectives, Processes, and Context $2^{\text {nd }}$ ed. New York: McGraw-Hill

Mujani, Saiful. (2007). Muslim Demokrat. Jakarta: Gramedia Pustaka Utama

Nurudin. (2004). Komunikasi Massa. Malang: CESPUR

Shoemaker, Pamela J. (1991). Gatekeeping. Newsbury Park: Sage Publications

Shoemaker, Pamela J. Dan Stephen D. Reese. (1996). Mediating the Message: Theories of Influence on Mass Media Content $2^{\text {nd }}$ ed. New York: Longman

Sudibyo, Agus dkk. (2001). Kabarkabar Kebencian: Prasangka Agama di Media Massa. Institut Studi Arus Informasi (ISAI)

Syahputra, Iswandi. (2006). Jurnalisme Damai: $\quad$ Meretas Ideologi Peliputan di Area Konflik. Yogyakarta: Pilar Media

Turner, Bryan S (Eds.). (2006). The Cambridge Dictionary of Sociology. Cambridge: Cambridge University Press

Utomo, Anif Punto. (2010). Republika: 17 Tahun Melintasi Zaman. Jakarta: Harian Umum Republika

Referensi Karya Ilmiah, Makalah, Jurnal, dan Publikasi

Semma, Mansyur. (1998). Studi "Gatekeeping" dalam Pemberitaan $\mathrm{Su}$ rat Kabar Indonesia: Analisis Isi Informasi Peristiwa Timor Timur dan Situbundo di Harian Kompas, Suara Pembaruan, dan Republika. Tesis. Universitas Indonesia.

Survei LSI, September 2005 dalam LSI. (Februari 2008). Kajian Bulanan Lingkaran Survei Indonesia EDISI 10. Jakarta: Lingkaran Survei Indonesia 


\section{Referensi Internet}

Raden Trimutia Hatta. (2009). Tuduhan Istri Boediono Katolik tak Bermoral. Dalam http://www.inilah.com/berita/polit ik/2009/06/02/112012/tuduhanistri-boed -katolik-tak-bermoral/. Diunduh pada tanggal 21 Juni 2009 pukul 20:55 WIB

\section{Referensi Surat Kabar dan Majalah}

Mega Prabowo Sepakat. (15 Mei 2009). Suara Merdeka: Hal 1

JK: Jangan Suruh Istri Saya Lepas Jilbab. (1 Juni 2009). Republika: Hal 8 kolom 6
Masyarakat Diminta Maafkan Ruhut. (3 Juni 2009). Republika: Hal 5, kolom 2

'Ekonomi Syariah Opsi Serius'. (9 Juni 2009). Republika: Hal: 1, kolom 2

Istri Boediono Diserang. (25 Juni 2009). Republika. Hal: 5, kolom 2

Kasus Herawati Boediono di-Bawaslukan. (26 Juni 2009). Republika: Hal 4, kolom 1

Satu Mentari Dua Warna. (30 Maret 2009). Tempo: 69

Semangat Populis Partai Dakwah. (30 Maret 2009). Tempo: 51 